www.jmscr.igmpublication.org

Impact Factor 5.244

Index Copernicus Value: 83.27

ISSN (e)-2347-176x ISSN (p) 2455-0450

crossref DOI: http://dx.doi.org/10.18535/jmscr/v4i10.02

Journal Of Medical Science And Clinical Research

\title{
Thrombosis Associated with Protein S Deficiency: A Case Report and Literature Review
}

\author{
Authors \\ Adnan Bashir Bhatti, MD ${ }^{1}$, Farhan $\mathrm{Ali}^{2}$, Siddique Akbar Satti ${ }^{3}$, Shuja Ur Rehman ${ }^{4}$ \\ ${ }^{1}$ Dept of Medicine, Capital Development Authority (CDA) Hospital, Islamabad, Pakistan \\ ${ }^{2}$ Department of Medicine, Capital Development Authority (CDA) Hospital, Islamabad, Pakistan \\ ${ }^{3}$ Department of Medicine, Capital Development Authority (CDA) Hospital, Islamabad, Pakistan \\ ${ }^{4}$ Department of Medicine, Capital Development Authority (CDA) Hospital, Islamabad, Pakistan \\ Corresponding Author
}

Adnan Bashir Bhatti, MD

Email:dr.adnanbashir@gmail.com

\begin{abstract}
We have reported a rare case of deep vein thrombosis (DVT) of both legs due to protein $S(P S)$ deficiency in a 28-year-old female. She was admitted to intensive care unit (ICU) on the basis of lower limb swelling due to thrombosis as confirmed by Doppler ultrasonography. Immunoassay by ELISA demonstrated markedly reduced total PS levels in her serum, which is likely due to a defect in the PROS1 gene. The patient was successfully treated with heparin and warfarin. This case adds to the growing evidence that PS deficiency is one of the rare cause of DVT, and also raises awareness about prophylactic treatment especially in those with PROS1 gene abnormalities or other risk factors.

Keywords: Thrombosis, protein S deficiency, PROS1 gene, deep vein thrombosis.
\end{abstract}

\section{Introduction}

Protein S (PS) is a vitamin K-dependent serum protein, of $75 \mathrm{kDa}$, that has a pivotal role in the anticoagulant system ${ }^{[1]}$. Its major function is as a cofactor to facilitate the action of activated protein $\mathrm{C}$ (APC) on its substrates, activated factors $\mathrm{V}$ $(\mathrm{FVa})$ and $(\mathrm{FVIIIa})^{[2]}$. Deficiency of PS is rare ${ }^{[3]}$, but has been associated with deep vein thrombosis (DVT) ${ }^{[4]}$, thrombophlebitis ${ }^{[5]}$, and pulmonary embolism ${ }^{[6]}$. We described a case of young female presented with deep venous thrombosis (DVT) in both legs due to PS deficiency.

\section{Case Report}

A 28-year-old normotensive and normoglycemic female presented in the emergency department (ER) of the Capital Development Authority (CDA) Hospital, Islamabad, Pakistan, with sudden onset painful swelling of both legs for last seven days. Her past medical and surgical history were unremarkable, and she belongs to low socioeconomic status. Her menstrual cycle was regular, and her two children were delivered by caesarean section without any bleeding and thrombotic complications during or after delivery. She used oral contraceptive pills (OCP) intermittently, and her family history was unremarkable. 
The patient physical examination showed $80 \mathrm{~kg}$ (176lbs) and $4 \mathrm{ft} 7$ in $(140 \mathrm{~cm})$ weight and height, respectively. There were no features of jaundice, pallor, leukonychia, clubbing, edema, lymphadenopathy. Her vital signs were within normal limited.

Both legs were swollen with right and left calf circumferences of 48.5 and $47.5 \mathrm{~cm}$, respectively, and the overlying skin was congested as shown in Figure 1. The respiratory, gastrointestinal, cardiovascular, and central nervous system examinations were all normal. Thrombosis was detected by Doppler ultrasound exam on both lower limbs, right femoral vein and left popliteal vein.

Investigations revealed normal complete blood count (CBC). Complement levels, antinuclear antibody (ANA), anti-smooth muscle antibody (SMA), anti-double stranded DNA (dsDNA), anticardiolipin antibodies (ACA), anti-mitochondrial antibodies (AMA) and rheumatoid factor (RF) were found to be undetectable which rules out the possibility of autoimmune diseases. Bleeding time, clotting time, activated partial thromboplastin time (APTT), and prothrombin time (PT), serum protein $\mathrm{C}$ were also within normal limits, while serum PS test was on lower limits $24 \mathrm{U} / \mathrm{dl}$ (normal > $63 \mathrm{U} / \mathrm{dl}$ for females).

The diagnosis of PS deficiency was made on the basis of low PS levels. The patient was admitted, and started on low molecular weight heparin (LMWH) along with warfarin. Prothrombin time (PT) and INR (International Normalized Ratio) were monitored. The treatment goal was to maintain INR range from 2-3, and prevent potential complications.

Patient was stable and discharged on the tenth day of hospital stay, on warfarin $10 \mathrm{mg}$ once a day with INR 2.6; and advised to follow-up monthly to monitor INR, CBC and serum PS level.

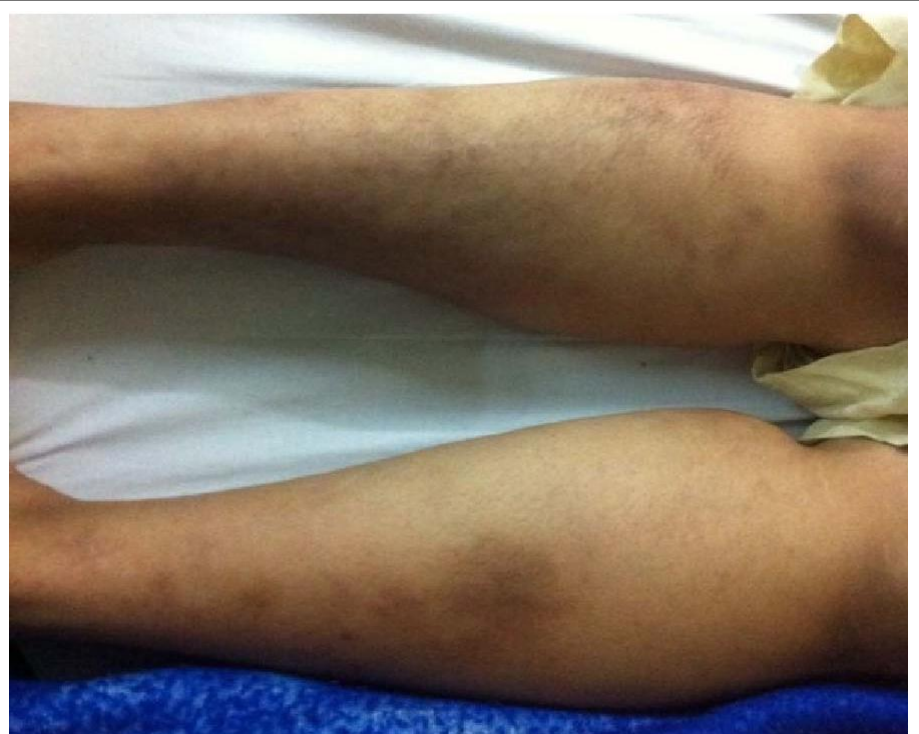

Figure 1: Enlarged and swollen calves of the 28year-old female with DVT.

\section{Discussion and Literature Review}

The present case adds to the growing evidence that PS deficiency is associated with thrombosis ${ }^{[3,4]}$. This is perhaps not surprising since PS has a crucial role in the control of normal blood clotting via inhibition of coagulation ${ }^{[1,2]}$. It does this through a feedback mechanism in which it activates activated protein C (APC) eventually leading to proteolysis and breakdown of coagulants and products ${ }^{[10]}$. In addition, PS has anticoagulant properties even in the absence of APC since it is able to inhibit thrombin production [11], and a role in the tissue factor pathway inhibitor (TFPI) system has been proposed ${ }^{[1,12]}$. The deficiency may be either acquired ${ }^{[13]}$, or hereditary ${ }^{[3,4]}$. It is detected in about 1:700 of the general population although its frequency is markedly increased to $3-6 \%$ in subjects with thrombophilic disorders, further indicating its pivotal role in thrombosis ${ }^{[4,7]}$. Acquired forms can occur as a result of a number of factors such as low vitamin-K levels, liver disease, HIV infection, sickle-cell anemia, and in warfarin therapy ${ }^{[13-15]}$. Inheritable forms are rare, with an incidence of about $0.03 \%{ }^{[4]}$ and usually due to large deletions in the PS gene, PROS1 ${ }^{[16]}$, although other defects such a frameshift ${ }^{[17]}$, and nonsense mutations have been described ${ }^{[18]}$. Since PS deficiency is autosomal-dominant (AD), even one allele may 
still be wild type, heterozygous individuals have an increased risk of thrombophilic events and their PS levels are diminished ${ }^{[16]}$. Without molecular analysis of the relevant gene, it is difficult to decipher whether any observed PS deficiency is acquired or inheritable ${ }^{[19]}$. Unfortunately, due to the lack of facilities in the hospital, it was not possible to assess the PROS1 gene in the present case. Nevertheless, there are some differences in serum biochemistry and phenotypic presentation between the acquired and inheritable forms [16] and the latter is usually associated with DVT rather than arterial thrombosis ${ }^{[20]}$. In our case patient had DVT in both legs revealed by doppler ultrasound examination. In addition, deficiency of PS predisposes to recurrent venous thromboembolism (VTE) ${ }^{[4,21]}$. Thus, although there was no family history of thrombosis, the patient's history of the previous DVT is consistent with PS deficiency due to a possibly inheritable gene defect. In support of this, no factor associated with acquired PS deficiency was found.

The diagnosis of PS deficiency can be achieved by either assessing biological activity or immunoassay [19]. Immunoassays can measure both free and bound forms. Careful evaluation is required to interpret the results correctly since many factors can influence serum PS levels including other diseases, pregnancy, use of oral contraceptives, insufficient vitamin-K intake, and medication with vitamin-K antagonists activity ${ }^{[3,13,15]}$. Three broad types have been described in the literature ${ }^{[22,23]}$. Type-I - is characterized by a decrease in both free and total PS. Type-II represents functional deficiency, since total free and bound PS are normal. Type-III - occurs when the free is low but total PS is normal. An ELISA for total PS was used to monitor the present case and concluded that the patient suffered from the type-I form of PS deficiency.

Because of the associated increased risk of thrombophilic events, PS deficiency should be clinically addressed ${ }^{[24]}$. This could include the use of prothrombin complex concentrates ${ }^{[25]}$. Oral contraceptives are contraindicated because of their lowering effects on PS and association with thrombosis ${ }^{[9]}$. In the event of presenting thrombophilic events, the initial treatment consists of unfractionated heparin or low molecular weight heparin (LWHM) in conjunction with warfarin until an INR of 2.0-3.0 is reached on two consecutive days ${ }^{[21,26]}$. Heparin should be administered for at least 5 days to prevent skin necrosis, a rare adverse effect that occurs during early warfarin treatment in patients with PS and protein $\mathrm{C}$ deficiency ${ }^{[15]}$. Warfarin treatment should be considered for up to 2 years, and in some cases for life-long ${ }^{[21]}$.

\section{Conclusion}

We reported a rare cause of a deep vein thrombosis of both legs due to protein $\mathrm{S}$ deficiency in a 28-year-old female. Clinicians should have a high index of suspicion of such rare causes of thrombophilia, when evaluating DVT to prevent life-threatening complications.

\section{Author Contributions}

$\mathrm{AB}$ Bhatti clinically examined the patients and diagnosed protein $\mathrm{S}$ deficiency. F Ali supervised the laboratory biochemical studies. SA Satti helped confirm the clinical and laboratory diagnosis.

\section{References}

1. Hackeng TM, Rosing J. Protein $S$ as cofactor for TFPI. Arterioscler Thromb Vasc Biol 2009;29:2015-20.

2. Castoldi E, Hackeng TM. Regulation of coagulation by protein S. Curr Opin Hematol 2008;15:529-36.

3. Qi X, De Stefano V, Wang J, Bai M, Yang Z, Han G, Fan D. Prevalence of inherited antithrombin, protein $\mathrm{C}$, and protein $\mathrm{S}$ deficiencies in portal vein system thrombosis and Budd-Chiari syndrome: a systematic review and meta-analysis of observational studies. J Gastroenterol Hepatol 2013;28:432-42. 
4. Brouwer JL, Lijfering WM, Ten Kate MK, Kluin-Nelemans HC, Veeger NJ, van der Meer J. High long-term absolute risk of recurrent venous thromboembolism in patients with hereditary deficiencies of protein $\mathrm{S}$, protein $\mathrm{C}$ or antithrombin. Thromb Haemost 2009;101:93-9.

5. de Godoy JM, Braile DM. Protein S deficiency in repetitive superficial thrombophlebitis. Clin Appl Thromb Hemost. 2003;9:61-2.

6. Bignon M, Dahdouh Z, Roule V, Grollier G. Massive pulmonary embolis arising from a bifid ovarian vein in a patient with protein $\mathrm{S}$ deficiency. Cardiol $\mathrm{J}$ 2011;18:701.

7. Dykes AC, Walker ID, McMahon AD, Islam SI, Tait RC. A study of Protein S antigen levels in 3788 healthy volunteers: influence of age, sex and hormone use, and estimate for prevalence of deficiency state. Br J Haematol 2001;113:636-41.

8. Witt DM, Delate T, Clark NP, Martell C, Tran T, Crowther MA, Garcia DA, Ageno W, Hylek EM. Outcomes and predictors of very stable INR control during chronic anticoagulation therapy. Blood 2009;114;952-6.

9. Quehenberger P, Loner U, Kapiotis S, Handler S, Schneider B, Huber J, Speiser W. Increased levels of activated factor VII and decreased plasma protein $\mathrm{S}$ activity and circulating thrombomodulin during use of oral contraceptives. Thromb Haemost 1996;76:729-34.

10. Rosing J, Hoekema L, Nicolaes GA, Thomassen MC, Hemker HC, Varadi K, Schwarz HP, Tans G. Effects of protein S and factor $\mathrm{Xa}$ on peptide bond cleavages during inactivatiuon of factor $\mathrm{Va}$ and factor VaR506Q by activated protein $\mathrm{C}$. J Biol Chem 1995;270:27852-58.

11. Vanteer C, Hackeng TM, Biesbroeck D, Sixma JJ, Bouma BN. Increased prothrombin activation in protein $\mathrm{S}$ - deficient plasma underflow conditions on endothelial cell-matrix - an independent anticoagulant function of protein $S$ in plasma. Blood 1995;85:1815-21.

12. Hackeng TM, Sere KM, Tans G, Rosing J. Protein $\mathrm{S}$ stimulates inhibition of the tissue factor pathway by tissue factor pathway inhbitior. Proc Natl Acad Sci USA 2006;103:3103-111.

13. Kemkes-Matthes B. Acquired protein $S$ deficiency. Clin Investig 1992;70:529-34.

14. Mochan A, Modi M, Modi G. Protein S deficiency in HIV associated ischaemic stroke: an epiphenomenon of HIV infection. J Neurol Neurosurg Psychiatry. 2005;76:1455-6.

15. Liaw TY, Chang CH. Skin necrosis complicated by warfarin-induced protein $\mathrm{S}$ deficiency. J Formos Med Assoc 2014;113:758-9.

16. Duebgen S, Kauke T, Marschall C, Giebel A, Lison S, Hart C, Dick A, Spannag M. Genotype and laboratory and clinical phenotypes of protein S deficiency. Am J Clijn Pathol 2012;137:178-84.

17. Hwang RA, Gausman JN. Portal-SplenicMesenteric Venous Thrombosis in a Patients with Protein S Deficiency due to Novel PROS1 Gene Mutation. Korean J Gastroenterol 2014;64:110-4.

18. Jang MA, Kim SH, Kim DK, Kim HJ. A novel nonsense mutation Tyr301 of PROS1 causing protein $\mathrm{S}$ deficiency. Blood Coagul Fibrinolysis 2014 Sep [Epub ahead of print].

19. Marlar RA, Gausman JN. Protein S abnormalities: a diagnostic nightmare. Am J Hematol 2011;86:418-21.

20. Soare AM, Popa C. Deficiencies of proteins $\mathrm{C}, \mathrm{S}$ and antithrombin and factor $\mathrm{V}$ and the risk of ischemic strokes. J Med Life 2010;3:235-8.

21. Ten Kate MK, van der Meer J. Protein S deficiency: a clinical perspective. Haemophilia 2008;14:1222-8. 
22. Gladson CL, Scharrer I, Hach V, Beck $\mathrm{KH}$, Griffin JH. The frequency of type I heterozygous protein $\mathrm{S}$ and protein $\mathrm{C}$ deficiency in 141 unrelated young patients with venous thrombosis. Thromb Haemost 1988;59:18-22.

23. Wypasek E, Undas A. Protein C and protein $\mathrm{S}$ deficiency - practical diagnostic issues. Adv Clin Exp Med 2013;22:45967.

24. Seligsohn U, Lubetsky A. Genetic susceptibility to venous thrombosis. N Engl J Med 2001; 344: 1222-31.

25. Lechler E. Use of prothrombin complex concentrates for prophylaxis and treatment of bleeding episodes in patients with hereditary deficiency of prothrombin, factor VII, factor X, protein C protein S, or protein Z. Thromb Res 1999;95 (suppl 1):S39-50.

26. Holzheimer RG. Low-molecular-weight heparin (LMWH) in the treatment of thrombosis. Eu J Med Res 2004;30:22539. 